\title{
FACTORS INFLUENCING E-COMMERCE ADOPTION AMONG MALAY WOMEN ENTREPRENEURS IN KUCHING SARAWAK
}

\author{
Haniffah Haziqah Hussin \\ Faculty of Business Management, Universiti Teknologi MARA, Kota Samarahan, \\ Sarawak, Malaysia
}

Mohd Azizee Jemari

Faculty of Business Management, Universiti Teknologi MARA, Kota Samarahan, Sarawak, Malaysia

\section{Jati Kasuma}

Faculty of Business Management, Universiti Teknologi MARA, Kota Samarahan, Sarawak, Malaysia

\section{Yusman Yacob}

Faculty of Business Management, Universiti Teknologi MARA, Kota Samarahan, Sarawak, Malaysia

\section{Ratnawate Panie}

Faculty of Business Management, Universiti Teknologi MARA, Kota Samarahan, Sarawak, Malaysia

*Corresponding author

Email address: jatikasuma@hotmail.com

\begin{abstract}
Nowadays, women entrepreneurs have become part of the important factor in the world of entrepreneurship in terms of economic development contributions and social inclusion. Moreover, the ability of small and medium-sized enterprises (SMEs) to foster innovation, experimentation, and adaptation in the business environment is crucial for countries undergoing radical transformation. 140 respondents were involved in this survey which was conducted for two weeks and the data from the questionnaires were analysed and computed by using mean score, regression and correlation. This paper aims to investigate the factors that affect the adoption of E-Commerce by Malay women entrepreneurs in Kuching Sarawak. Variables are categorized based on different E-Commerce adoption context which include technological factors, organizational factors and environmental factors with additional of benefits and barriers of E-Commerce adoption are expected to affect the adoption of ECommerce. Quantitative approach was used for this study. The findings indicate that perceived relative
\end{abstract}


advantage was the most influencing factor in the adoption of E-Commerce among Malay women entrepreneurs in Kuching Sarawak. Furthermore, the finding from this study complements several prior studies. Only perceived relative advantage, cost and competitive pressure has the ability in predicting the level of E-Commerce adoption. This study also highlights that perceived benefit from adopting ECommerce by Malay women entrepreneurs to be imminent as it provides access to new markets. This study also shows that Malay women entrepreneurs in Kuching Sarawak have yet to utilize E-Commerce technologies despite having acknowledged perceiving the benefits that can be obtained by adopting ECommerce.

Keywords: E-Commerce adoption, Malay women entrepreneurs

\section{INTRODUCTION}

Nowadays, women entrepreneurs have become part of the important factor in the world of entrepreneurship in terms of economic development contributions and social inclusion. Moreover, the ability of small and medium-sized enterprises (SMEs) to foster innovation, experimentation, and adaptation in the business environment is crucial for countries undergoing radical transformation (European Bank for Reconstruction and Development, 1994). Researcher such as Welter, Smallbone, Isakova, Aculai and Schakirova (2004) suggested that female-owned enterprises are obviously important in the context of transitioning countries for a number of additional reasons. First, they tend to employ other women more frequently, which helps reduce the effect of discrimination against women in the labour market. Second, by reducing female unemployment, women-owned SMEs can assist in fighting the trafficking of women, which is of great concern in many transition countries. Third, female business owners can serve as role models for younger generations demonstrating new opportunities for employment. In addition, by encouraging potential female entrepreneurs to start businesses could result in the increase of innovative capacities and development in the private sector. Meanwhile, development of entrepreneurship, together with human skills improvement have become two crucial factors for a country to be a world leader in all aspects of life, e.g., economy, trade, military, technology, etc., and for a sustainable economic and social development (Fuad \& Bohari, 2011). Most of the recent researches in Malaysia on Electronic Commerce (EC) have focused on the Business-to-Consumer segment of e-commerce activity (Khairul \& Ahmad 2005; Khatibi, Thyagarajan, \& Seetharaman, 2003; Jawahitha, 2004). However, greater potential in business e-commerce have encouraged companies to move from traditional method to the online business worldwide. Electronic Commerce (E-Commerce) involves the sale, purchase, transfer or exchange of products, services and/or idea (information) over a computer media including Internet and World Wide Web by businesses, individuals, Governments or other organizations. E-Commerce builds on typical traditional commerce by adding flexibility and speed that is offered by electronic communication (C.Laudon, et al., 2009). E-commerce researchers reported tremendous growth in E-Commerce all over the globe due to the enormous number of goods and services traded among firms (Laudon \& Traver, 2001; Garicano and Kaplan 2001). Chairperson of Sarawak Chamber of Bumiputera Entrepreneurs (DUBS Dewanita) said that, much research has been done showing that women were the most vulnerable but also the biggest strength leading to economic progress. "The key players at the moment are women, who may hold the most potential for jumpstarting global growth," (Borneo Post Online, 2013). Malay women entrepreneurs involved in various sectors such as Manufacturing, Food Industry (Food \& Beverages/Restaurant), Retailing \& Wholesaling, Beauty \& Health Product, Saloon \&Spa, Services, Contractor, Electrical \& Electronic goods \& services, Handicrafts, Hurdle \& Others (UPUB, 2014). In addition, understanding factors affecting e-commerce adoption help managers of SMEs to predict e-commerce usage rate and evaluate the future growth of e-commerce. Most researchers have been concentrated on the e-commerce adoption in the world. However, there is still a need for closer examination on the e-commerce adoption rate in specific countries. Still there is a big research gap exists, especially between the developed and 
developing countries, which may differ significantly between countries (Licker and Motts 2000; Spanos et al. 2002) that limit the generalization of research results from developed countries to developing country contexts (Dewan and Kraemer 2000). The use of Electronic Commerce (E-Commerce) enables Small and Medium Enterprises (SMEs) to improve their efficiency and competitive advantage. Although researchers have been increasingly exploring and predicting ecommerce adoption among SMEs in other developing countries, there is still a limited understanding of the behaviour of Malaysian SMEs towards E-Commerce technologies adoption. As in many other countries, the SME sector constitutes the majority of business activities in Malaysia, and their contribution to Malaysian economy is very significant. Yet, very little research on Malay women SMEs in Sarawak has taken a holistic view of the e-commerce adoption factors, from technological, organizational and environmental contexts. This paper therefore examines the determinants of E-Commerce adoption among Malay women entrepreneurs in Kuching Sarawak. The rest of the paper will identify the important factors, benefits and barriers that influencing adoption of E-Commerce among Malay women entrepreneurs in Kuching.

Generally, both men and women who desire to be self-employed undertake entrepreneurial activities. In the Malaysia SME sector, women's participation in entrepreneurship and their economic contribution is minute when compared to men when the government recognize. Among Malaysian SMEs, $16 \%$ or close to 83,000 businesses are owned by women entrepreneurs, based on the census in 2005 (MITI, 2009). This low representation of women entrepreneurs makes Malaysia's SME sector male dominant. The role of women in the country's development has risen to new heights when the government recognized their contribution to the economy. Malaysia government established the National Women Policy (NWP) as means to enhance women participation in economic activities, besides workforce, social and political aspects (Panie, Kamarudin, \& Ali, 2012). Furthermore, discrepancies were found to exist in similar studies especially between the developed and developing countries (Licker and Motts 2000; Spanos et al. 2002) that limit the overview of research results from developed countries to developing country contexts (Dewan and Kraemer 2000). Given the differences in the factors influencing E-Commerce adoption from one country to another country, there is a need to investigate what are the factors that actually influence E-Commerce adoption; to be specific ECommerce adoption among Malay women entrepreneurs. Not all of Malay women entrepreneurs are utilizing the E-Commerce Technology. Thus, to what extent the usage of IT applications in business among women Malay entrepreneurs are yet to be determined. The researcher has selected the Kuching area as the target respondent due to the important role of Malay women entrepreneurs in improving the Sarawak economy which will directly enhancing the well-being.

The research objectives of this research are to to examine demographic characteristics of Malay women entrepreneurs that are adopting E-Commerce technologies and to investigate level of ECommerce adoption by Malay women entrepreneurs in Kuching Sarawak. Next, research objective are to determine factor/s (Technological, Organizational, Environment) influencing E-Commerce adoption by Malay women entrepreneurs and investigating the benefits and barriers of E-commerce adoption perceived by Malay women entrepreneurs.

\section{LITERATURE REVIEW}

Electronic Commerce (E-Commerce) involves the sale, purchase, transfer or exchange of products, services and/or idea (information) over a computer media including Internet and World Wide Web by businesses, individuals, Governments or other organizations. E-Commerce builds on typical traditional commerce by adding flexibility and speed that is offered by electronic communication. This can facilitate competitiveness and efficiency through redesign of traditional business method. E-Commerce is the application of current and emerging information and communication technologies (ICTs) to conduct businesses. These applications include existing technologies like landline telephone and fax, but the ICTs offering most scope for small businesses are more mobile phones, electronic mail and other Internet-based services. However, E-Commerce is not just about using new technologies. ECommerce also covers outward-facing processes that touch customers, suppliers and external partners, including sales, marketing, order taking, delivery, customer service, purchasing of raw materials and supplies for production and procurement of indirect operating-expense items, such as office suppliers. 
It involves new business model and the potential to gain new revenue or lose some existing revenue to new competitors (Laudon K. C., Traver, Alam, Saihani, \& Mohamed Noordin, 2012).

In Malaysian context, the studies on SME have not yet reached an in-depth analysis on the development of SME in many major areas especially concerning the issues of electronic endeavour. The SMI Association of Malaysia reported that ICT implementation among local SMEs is still at a very basic level. According to the Secretary of the association, about $90 \%$ of the 100,000 local SMEs use PCs for simple operations such as basic accounting, financial data and word processing. Only about $30 \%$ of the local SMEs have some kind of web presence and use technology in their daily operations. In another study, it was found that, in 2000 , about $50 \%$ of the SMEs have websites for online advertising, and $43 \%$ take orders on the Internet. This finding indicates that SMEs in Malaysia are beginning to take up Internet-based business. Due to the global reach of E-Commerce, in the developed countries, Small and Medium-sized Enterprises (SMEs) have started applying E-Commerce in their businesses (Rao and Metts 2003); but SMEs in Malaysian and many other developing countries are still resist to use Information Technology or E-Commerce in their daily business operation. In conclusion, e-commerce in Malaysia is still in its infancy, but the future is bright with the support from government in term of incentives, grants and development program, SMEs are supposed to be able to go forward in E-Commerce technology. However, many SME are way at the back in the concern on E-Commerce and lack of awareness about the importance of E-Commerce technology in promoting the businesses.

Scholarly literature on women's entrepreneurship is multidisciplinary, grounded in a diverse theoretical framework (e.g., Inman, 2000; Mirchandani, 1999; Ahl, 2004; Buttner \& Moore, 1997; Carter, 2000; Edley, 2003; Essers \& Benschop, 2008; Bruni, Gherardi, \& Poggio, 2004). Notably, research on entrepreneurship also often assumes Western values such as individualism, competitiveness, material gain, and a strong work ethic (Morris \& Schindehutte, 2005). These values have portrayed entrepreneurial ideal as White, male, individualistic, and Western, and has shaped the study of entrepreneurship in management journals. In 1996, Malaysian women entrepreneurs (including sole proprietors and business partners) accounted for almost 25 percent $(400,000)$ of the total selfemployed population in Malaysia. In 2003, women's participation in small and medium enterprises was $1,122,000$ (in Teoh \& Chong, 2007). Ahmed et al. (2005) report that following independence, the Chinese held power in the economic and commercial sectors whereas the Malays did not capitalize on opportunities to increase their standard of living by becoming involved in business. Ultimately, the Malays began to feel discontented and deprived of their homeland due to inequality in wealth and income distribution. This discontent has led to the Malay resentment and distrust toward the economically dominant Chinese (Gomez, 1999; Abdullah, 1997). Considering the pluralistic nature of Malaysia, the discourse of Malayness or Bumiputeraism can be seen as problematic and contestable within the competing groups. In Malaysia, women's involvement in business has increased over the past two decades (Ismail, 2001; Omar \& Davidson, 2004). A significant contribution to their higher participation in business may be due to a lack of paid employment in both the public and private sectors, which has prompted women to engage in business activities. However, statistics on Malay women in business ownership are scarce and we have little information about how their gender, ethnicity and Muslim identity may influence women in their everyday business practices. Previous studies show that the predominant work on women's entrepreneurship have focused on Western countries, and been grounded in a functionalist perspective (Moore \& Butner, 1997; Inman, 2000; Carter 2000; Renzulli, Aldrich, \& Moody, 2000; Loscocco, Robinson, Hall, \& Allen, 1991). Thus, they fail to examine how entrepreneurship is very much a reflection of the societal context in which it is located.

\section{Factors Affecting the Adoption of E-Commerce by SMEs}

Perceived Relative Advantage: Relative Advantage refers to the level to which an innovation is perceived as being better than the idea it supersedes (Rogers, 2003). Relative advantage is viewed as an advantage for an organization over previous ways of performing the same task (Agarwal and Prasad 1997). Mohammed, Almsafir \& Alnaser (2013) found that perceived relative advantage was an important factor that influences E-Commerce adoption by SMEs. There are many of previous research found that this variable was positively influencing the adoption rate. When the firm perceived the relative advantage by adopting E-Commerce, the firm will be more likely to adopt E-Commerce (Lee 
et al., 2004). The finding is corresponding to several previous researches (Ramdani, Chevers, \& Williams, 2013; Mohammed, Almsafir \& Alnaser, 2013; Ghobakhloo, Arias-Ananda and BenitezAmado, 2011; Alam, Ali \& Jani, 2011; Ifinedo, 2011; Sin, 2009; Alam, Khatibi, Ahmad \& Ismail, 2008; Hussin \& Noor, 2005 and Seyal and Abd. Rahman, 2003).

Perceived Compatibility: Tornatzky and Klein (1982) found that an innovation will be adopted when it is compatible with individual job responsibility and value system. Compatibility of the innovation with a former idea can either speed up or hinder its rate of adoption in the organization. The extent to which innovation meets firm's need is another dimension of compatibility of an innovation. Compatibility of an innovation is defined as the extent to which an innovation is perceived as reliable with the existing values, previous experiences, and needs of potential adopters (Rogers, 2003). Ramdani, Chevers, \& Williams (2013) found that compatibility has been confirmed to be significant to be significant factors influencing SMEs' adoption of ICT. The adoption of new technologies can bring positive changes to the work practices of businesses and hinder to change is a normal organisational reaction (Premkumar and Roberts, 1999). Therefore, it is important that the innovation is compatible with firm's infrastructure, values and beliefs. If the E-Commerce is perceived as compatible with the firm's total business procedures, environment, values and beliefs, the firm will be more likely adopt it. This finding is corresponding to several previous researches (Ghobakhloo, Arias-Ananda and BenitezAmado, 2011; Alam, Ali \& Jani, 2011; Ifinedo, 2011; Gilaninia, Danesh, Amiri, Mousavian \& Eskandarpour, 2011; Sin, 2009; Alam, 2009; Alam, Khatibi, Ahmad \& Ismail, 2008 and Seyal and Abd. Rahman, 2003).

Perceived Complexity: Complexity is defined as the extent that where an innovation is perceived as relatively difficult to understand and implement (Rogers, 2003). The complexity of a technology leads to greater uncertainty for the successful implementation and therefore increases the risk in the adoption decision (Premkumar and Roberts, 1999). Ramdani, Chevers, \& Williams (2013) found that complexity is significantly affecting the adoption of ICT amongst SMEs. The finding was supported by other previous research (Ghobakhloo, Arias-Ananda and Benitez-Amado, 2011; Ifinedo, 2011; Sin, 2009; Hussin \& Noor, 2005 and Seyal and Abd. Rahman, 2003). Cost: Innovation cost is expected to give negatively effect on innovation adoption, where the more expensive the innovation, the less likely it will be adopted by the organisation (Mansfield 1968; Davis 1979). The E-Commerce costs consist of the investment in the process of its adoption (networks, PCs, data storage, demonstration, servers, software/hardware and other peripheral devices) (Wang and Tsai 2002). The lower the adoption cost the higher the new innovation such as the ICT will be adopted by the firm or vice versa. The SMEs will less likely to adopt ICT when the early set-up cost is high (Dixon et al, 2002). For the firm that is not interested in adopting E-Commerce may possibly think that it is not compulsory for their businesses, as it is too expensive to implement at the early stage of E-Commerce adoption. The cost factor was studied by prior research (Alam, 2009) has a positive influence on the internet adoption among Malaysian SMEs.

Size of Firm: Ramdani, Chevers, \& Williams (2013) found that size of firm under the organisational context is one of the significant factors influencing SMEs' adoption of ICT. Many of the literature, supports that firm size is a main predictor affecting the adoption of technology (Damanpour, 1992) and that size makes for toughness to any environmental changes. Previous studies show that SMEs are apparently a key factor for the development of Internet-based commerce (Troye-Walker, 1998) but its uptake is slower in smaller firms rather than larger firms (OECD, 2000). Zhu et al (2003) examine that larger firms have numerous advantages over smaller firms in the context of E-Commerce adoption. Amongst them are their tendencies to have more slack resources to facilitate adoption, economies of scale advantage, and their possibility to bear high risk linked with new innovation, and their control to persuade trading partners in adopting technology with network externalities. Jeyaraj et al. (2006) has been identified that size is one of the best factors that influencing organizational to adopt ICT. The typical discrepancy is that larger firms have a greater need, resources, skills and experience and the capability to survive failures than the smaller firms (Levenburg et al., 2006; Yap, 1990). Seyal and Abd. Rahman (2003) shows that size of firm is one of the factors that significantly contributing to ECommerce adoption among SMEs in Brunei. 
Top Management Support: Ramdani, Chevers, \& Williams (2013) found that top management support is one of the significant factors influencing SMEs' adoption of ICT. Top management can stimulate transformation by communicating and reinforcing values through an articulated vision for the organization (Thong, 1999). Many studies found that top management support is one of the critical in creating a supportive climate in adopting new technologies (Premkumar and Roberts, 1999; Grover and Goslar, 1993). In SMEs, the decision maker usually those who in the top management team and his/her support are crucial for the adoption to be implementing. This factor was studied by other previous research and has a significant relationship with the adoption of E-Commerce (Ifinedo, 2011; Scupola, 2009; Hussin \& Noor, 2005; Seyal and Abd. Rahman, 2003).

Organizational Readiness: Definition of organizational readiness is the availability of the needed organizational resources for the adoption (Iacovou et al., 1995). Organisational readiness, as used in prior study on the adoption of ICT among SMEs, examine whether a firm has sufficient ICT complexity and financial resources (Ramdani, Chevers, \& Williams, 2013). The level of organizational readiness has frequently been identified as a factor that influencing the successful of IT adoption (Grandon and Pearson 2002; Thatcher and Foster 2002; Chwelos et al. 2001; Crook and Kumar 1998; Iacovou et al. 1995). Technological capabilities or the level of use of innovative knowledge and skills of the firm reflects an organizational readiness (Dosi 1991). Without such capability an organization will be lacks of readiness and will be less likely to adopt innovation. SMEs with lack of readiness might incur higher initial costs when adopting innovation (Wang \& Tsai 2002). This is supported by previous study that used this variable in their study. It shows that there is significant relationship between organizational readiness with the adoption of E-Commerce (Shaharudin, Omar, Elias, Ismail, Ali \& Fadzil, 2012; Alam, Ali \& Jani, 2011; Ifinedo, 2011).

Types of Industry: Based on previous studies (Ramdani, Chevers, \& Williams, 2013 and Seyal and Abd. Rahman, 2003) result shows that industry in which the firm operates will influence the adoption of E-Commerce and ICT among SMEs. Service industries, which rely on the processing of information, are depending on the ICT (Goode and Stevens, 2000). Retail industries, which rely on the transport of goods, may have a greater reliance on point-of-sale systems (Premkumar and King, 1994). Manufacturing industry is more relying on ERP systems. ICT usage is varies not only across the sectors (i.e. across Standard Industrial Classification) but also within the constituent sub-sectors (Fallon \& Moran, 2000).

Competitive Pressure: In innovation adoption literature, competitive pressure is recognized as an adoption driver (Grover, 1993). In general, firms that dreams to exploit the environment to their own advantage must be proactive in decision-making or time action to reflect the moment they can set the industry pace to the disadvantage of opponents. Competitive pressure has been confirmed by Ramdani, Chevers, \& Williams (2013) as one of the significant factors that influencing SMEs' adoption of ICT. In the adopter's industry, competition is generally perceived to positively influence the decision in adopting ICT (Gatignon and Robertson, 1989). This is argued to be even more evident if the innovation directly affects the competition (Kuan \& Chau, 2001; Premkumar \& Roberts, 1999). Premkumar and Ramamurthy (1995) mentioned that the adoption of new technologies will become a strategic necessity to compete in the marketplace. This is supported by previous study that used this variable in their study. It shows that there is significant relationship between competitive pressure with the adoption of ECommerce (Ghobakhloo, Arias-Ananda \& Benitez-Amado, 2011; Ifinedo, 2011).

Buyer/Supplier Pressure: From the other viewpoint, pressure from customers and suppliers for electronic business was found to be another factor that influencing E-Commerce adoption and use within businesses (Barua et al., 2004; Oliveira and Martins, 2010) and therefore, pressure exerted by trading partners was exposed to be the main factor that influencing the EDI adoption within SMEs. In these businesses, some of the major factor of IS adoption such as internet-based commerce is satisfying suppliers' and customers' expectation by delivering superior electronic services and better communication with them (Caldeira \& Ward, 2003; Mehrtens et al., 2001; Riemenschneider et al., 2003). This perspective is corresponding with the concept of trading partners' e-business readiness, 
suggest that businesses which have adopted E-Commerce applications such as EDI and E-procurement systems influence and persuade their trading partners to adopt these applications as well to enhance their own benefits on E-Commerce adoption (Chwelos et al., 2001; Teo et al., 2009). This factor is supported by previous study where this factor has significant relationship with the adoption of ECommerce (Ghobakhloo, Arias-Ananda \& Benitez-Amado, 2011; Ifinedo, 2011; Alamro \& Tarawneh, 2011).

Supporting Industries: According to the IS literature, SMEs is suffering because of lack of in-house IS experts and complexity in outsourcing external consultants (Gable, 1991; Morgan et al., 2006). Cragg and Zinatelli (1995) pointed out that lack of internal expertise has critically prevents IS sophistication within the small firms and therefore, they must overcome this issue through either outsourcing the IS expertise or developing their own in-house end-users' computing skills (DeLone, 1981). Owing to the general financial constraint in SMEs, the businesses usually cannot afford costs of outsourcing the external IS expertise in order to provide training for employees, as well as to help them in adoption of IS (Thong and Yap, 1995; Thong, 2001). Hence, technology vendors can be considered as the major source of external IS expertise and an important factor in the adoption of IS within SMEs (Thong et al., 1997). As a result, it can be assumed that if CEOs of SMEs perceived the supports for E-Commerce adoption that are provided by vendors in E-Commerce applications, they would be more likely to adopt and intensely use these technologies.

Government Support: Both industry and government bodies play an important role in promoting and supporting small business networking and ICT. Australian governments are committed to accessible ECommerce for SMEs in that country, and have determined that some interference was essential to make participation affordable, particularly for small and remote businesses (Doig, 2000). In 1998, Doig (2000) also reported that a national framework was established to make sure that all Internet based ECommerce systems used by governments in Australia and New Zealand became completely interoperable, which benefited SMEs and their access to the marketplace. This variable was used in the previous study and it is supported that this factor has significant relationship with the adoption of ECommerce (Ifinedo, 2011 and Scupola, 2009).

Benefits of E-Commerce: Many previous theoretical and empirical studies have provided sufficient evidence that E-Commerce adoption can help firms/organization in improving their performance and reap benefits. Benefits of E-Commerce have been studied in many previous studies and it shows that these benefits have significant relationship with the adoption of E-Commerce (Alamro and Tarawneh, 2011; Gilaninia, Danesh, Amiri, Mousavian and Eskandarpour, 2011; Scupola, 2009). Measures of ECommerce benefits adapted from Zhuang and Lederer (2003) will be use in this study such as; (i)Better access to wider range of customers, (ii)Improve business processes flow, (iii)Reduced inventory costs, (iv)Provided access to new markets, (v)Increase the efficiency in dealing with suppliers.

Barriers of E-Commerce: Many factors could be responsible for the low usage of e-commerce among the SMEs in Malaysia. MITI (1999) suggested that the barriers behind the low adoption of Internet among the SMEs in Malaysia could be due to lack of understanding about ecommerce, doubts about its benefits, lack of qualified IT human resources, high implementation cost and worry about security. Furthermore, Economist Intelligence Unit (2001) also reported that credit card users in Malaysia are not willing to buy through the Internet due to security concerns. This might explain the slow adoption of e-commerce usage among businesses in Malaysia. Barriers of E-Commerce were studied by other previous research and have a positive relationship with the adoption of E-Commerce (Alamro and Tarawneh, 2011 and Scupola, 2009).

\section{Phases of E-Commerce Adoption}

As indicate by Boateng, R. Molla, A., Heeks, R. and Hinson, R. (2009), the hierarchical phases of ECommerce adoption that have been used in their research are; (i)No E-commerce, (ii)Connected ECommerce, (iii)Static E-Commerce, (iv)Interactive E-Commerce, (v)Transactive E-Commerce, and 
(vi)Integrated E-Commerce. This model also has been used in other previous studies (Al-Hudhaif \& Alkubeyyer, 2011; Laudon, Traver, Alam, Saihani \& Noordin, 2009; Tan, Tyler \& Manica, 2007; Aghaunor \& Fotoh, 2006; Dada, 2006 and Lai, Dahui, Wang \& Hutchinson, 2006). The phases of ECommerce adoption enable the firms/organizations with the following E-Commerce capabilities as stated below:

Table 2.1

Phases of E-Commerce Adoption

\section{PHASE}

Connected E- The intended E-Commerce ability is communication - the firms/organizations are using e-mail Commerce rather than Traditional ICT technologies, such as fax and telephone in order to support information and transactional processes. However, to reach of connected E-Commerce is limited for the existing and potential trading partners, suppliers and customers who know the firm's e-mail address and others the firm decides to contact.

\begin{tabular}{ll}
\hline $\begin{array}{l}\text { Static E- } \\
\text { Commerce }\end{array}$ & $\begin{array}{l}\text { Builds on connected E-Commerce and extends the communication capability to an } \\
\text { informational capability; where firms can inform trading partners, customers and suppliers of } \\
\text { their products and services through its website. This may increase their marketing reach. }\end{array}$ \\
\hline $\begin{array}{l}\text { Interactive E- } \\
\text { Commerce }\end{array}$ & $\begin{array}{l}\text { Creates an interactional capability, which adds the capability of online interactions and queries } \\
\text { between the firm and its customers to the informational capability. }\end{array}$ \\
$\begin{array}{l}\text { Transactive E- } \\
\text { Commerce }\end{array}$ & $\begin{array}{l}\text { Creates a transactional capability which goes beyond interactional capability to offer } \\
\text { transactional services such as an online purchasing capability for customers to purchase } \\
\text { products, track orders, and manage their account information. }\end{array}$ \\
\hline $\begin{array}{l}\text { Integrated E- } \\
\text { Commerce }\end{array}$ & $\begin{array}{l}\text { Creates a transformational capability, where the firm's website is integrated with suppliers, } \\
\text { customers, and other back-office systems allowing most business transactions and processes to } \\
\text { be conducted electronically. }\end{array}$ \\
\hline
\end{tabular}

\section{Technological Factors \\ - Perceived Relative Advantage \\ - Perceived Compatibility \\ - Perceived Complexity \\ - Cost}

\section{Organizational Factors}

- Size of Firm

- Organization Readiness

- Top Management Support

- Types of Industry

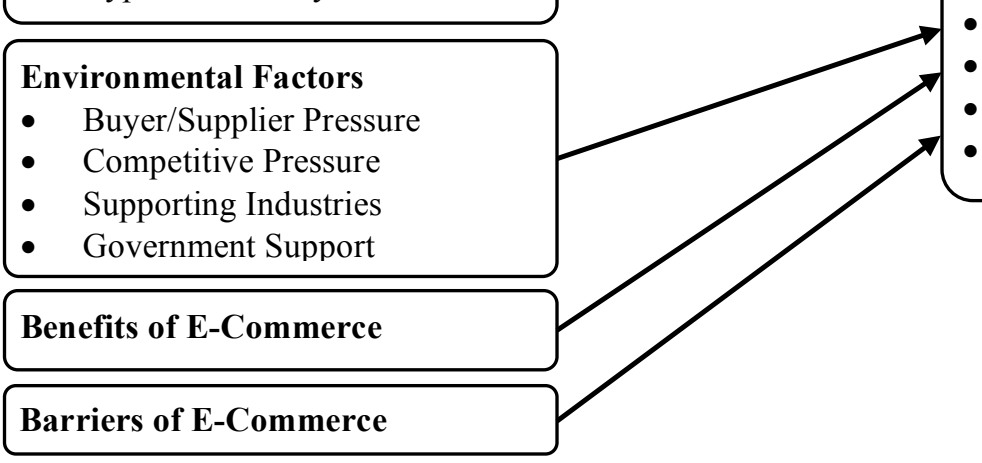

Figure 2.1: Theoretical Framework 
Sources: Ramdani, Chevers, \& Williams, 2013; Ghobakhloo, Arias-Aranda, \& Benitez-Amado, 2011; Ifnedo, 2011; Boateng, Molla, Heeks, \& Hinson, 2010.

\section{METHODOLOGY}

Researcher employed a quantitative data based research and a self-administered survey questionnaire was used as an instrument to collect data. The type of sampling used for this research was probability sampling technique by using snowball sampling method among the total population of Malay women entrepreneurs in Kuching. Based on the actual population list of women Malay entrepreneurs that generated by the Unit Pembangunan Usahawan Bumiputera (UPUB) Sarawak, the total population of women Malay entrepreneurs is 204 people which are currently operating their businesses in Kuching. The sample size will be determining based on Sekaran \& Bougie, 2010, where the sample size will only include 140 entrepreneurs. A total of 160 questionnaires were distributed in order to get higher response and only 140 questionnaires were completed and returned. In Section A will describe the respondents' demographic profile. In Section B and C, 5 Point of Likert Scale was used to assess respondents' level of agreement. Finally, open-ended questions were used to determine their opinions or suggestions on the given questions in Section D.

\section{FINDINGS AND DISCUSSIONS}

\section{Demographic Profile}

Total respondents for this study were 140 respondents which consist of Malay Women Entrepreneurs in Kuching Sarawak.

Table 4.1

Demographic Profile (Frequency Analysis)

\begin{tabular}{|c|c|c|c|}
\hline VARIABLES & ITEMS & $\mathrm{F}$ & $(\%)$ \\
\hline \multirow{3}{*}{ Category of SME } & Micro & 137 & 97.9 \\
\hline & Small & 3 & 2.1 \\
\hline & Medium & 0 & 0 \\
\hline \multirow[t]{2}{*}{ Type of Industry } & Manufacturing & 26 & 18.6 \\
\hline & Services and other sectors & 114 & 81.4 \\
\hline \multirow[t]{9}{*}{ Number of Full-time Employees } & Manufacturing: & & \\
\hline & Less than 5 employees & & \\
\hline & From 5 to less than 75 employees & 23 & 88.5 \\
\hline & From 75 to not exceeding 200 employees & 3 & 11.5 \\
\hline & & 0 & 0 \\
\hline & Services and other sectors: & & \\
\hline & Less than 5 employees & 114 & 100 \\
\hline & From 5 to less than 30 employees & 0 & 0 \\
\hline & From 30 to not exceeding 75 employees & 0 & 0 \\
\hline \multirow[t]{9}{*}{ Annual Sales Turnover } & Manufacturing: & & \\
\hline & Less than RM300,000 & & \\
\hline & From RM300,000 to less than RM15 million & 23 & 88.5 \\
\hline & From RM15 million to not exceeding RM50 & 3 & 11.5 \\
\hline & million & 0 & 0 \\
\hline & Services and other sectors: & 114 & 100 \\
\hline & Less than RM300,000 & 0 & 0 \\
\hline & From RM300,000 to less than RM3 million & 0 & 0 \\
\hline & From RM3 million to not exceeding RM20 million & & \\
\hline
\end{tabular}




\begin{tabular}{|c|c|c|c|}
\hline Business Type & $\begin{array}{l}\text { Manufacturing } \\
\text { Retailing \& Wholesaling } \\
\text { Beauty \& Health Product } \\
\text { Saloon \&Spa } \\
\text { Other Services } \\
\text { Construction } \\
\text { Electrical \& Electronic } \\
\text { Handicrafts } \\
\text { Agriculture } \\
\text { Hurdle Service Industry (Food Beverages } \\
\text { Food Sed } \\
\text { /Restaurant) } \\
\text { Others } \\
\end{array}$ & $\begin{array}{l}25 \\
8 \\
7 \\
7 \\
37 \\
0 \\
3 \\
7 \\
0 \\
0 \\
17 \\
29\end{array}$ & $\begin{array}{l}17.9 \\
5.7 \\
5.0 \\
5.0 \\
26.4 \\
0 \\
2.1 \\
5.0 \\
0 \\
0 \\
12.1 \\
20.7\end{array}$ \\
\hline Scope of your existing customers & $\begin{array}{l}\text { Local } \\
\text { Regional } \\
\text { Local \& Regional } \\
\text { Local, Regional \& Global/International }\end{array}$ & $\begin{array}{l}95 \\
0 \\
19 \\
26 \\
\end{array}$ & $\begin{array}{l}67.9 \\
0 \\
13.6 \\
18.6\end{array}$ \\
\hline $\begin{array}{l}\text { Is your firm/organization currently } \\
\text { adopting E-Commerce technology? }\end{array}$ & $\begin{array}{l}\text { Yes } \\
\text { No }\end{array}$ & $\begin{array}{l}93 \\
47\end{array}$ & $\begin{array}{l}66.4 \\
33.6\end{array}$ \\
\hline
\end{tabular}

The level of E-Commerce adoption among Malay women entrepreneurs (RO 1).

In this study, only $66.4 \%$ of the Malay women entrepreneurs are adopting E-Commerce and $33.6 \%$ are not adopting E-Commerce. Table 4.1 shows the mean analysis results for extent of e-commerce technologies adopted by Malay women entrepreneurs in Kuching Sarawak, with the sample population of 93 entrepreneurs. From the Table 4.1, it can be found that With Connected E-Commerce has the highest mean score amongst all the phases which is 3.30. It means that Malay women entrepreneurs were frequently used email alongside traditional ICT technologies, like fax and telephone, to support information and transactional processes. Second highest mean score is Static E-Commerce with 3.26. Malay women entrepreneurs are almost frequently extending the communication capability to an informational capability; where they can inform their trading partners, customers and suppliers of their products and services through their website. For Interactive E-Commerce and Transactive ECommerce, the mean scores are 2.17 and 1.39 respectively. From the results, it can be seen that Malay women entrepreneurs are not fully utilizing an interactional capability, which adds the capability of online interactions and queries between the firm and their customers to the informational capability and also not all the entrepreneur are using a transactional capability which goes beyond interactional capability to offer transactional services such as an online purchasing capability for customers to purchase products, track orders, and manage their account information.

Table 4.2

Extent of E-Commerce Technologies Adopted by Malay Women Entrepreneurs in Kuching Sarawak ( $N=93 /$ Adopters Only)

\begin{tabular}{lll}
\hline Extent of E-Commerce Adoption & Mean Score & Ranking \\
\hline $\begin{array}{l}\text { With Connected E-Commerce } \\
\text { Our firm is using email alongside traditional ICT technologies, like fax and } \\
\text { telephone, to support information and transactional processes. }\end{array}$ & $\mathbf{3 . 3 0}$ & $\mathbf{1}$ \\
\hline $\begin{array}{l}\text { Static E-Commerce } \\
\text { Our firm extends the communication capability to an informational capability; } \\
\text { where firms can inform trading partners, customers and suppliers of their products }\end{array}$ & 3.26 \\
and services through its website. & 2 \\
\hline $\begin{array}{l}\text { Interactive E-Commerce } \\
\text { Our firm is using an interactional capability, which adds the capability of online } \\
\text { interactions and queries between the firm and its customers to the informational } \\
\text { capability. }\end{array}$ & 3 \\
\hline
\end{tabular}




\begin{tabular}{lcc}
\hline Transactive E-Commerce & 1.39 & 4 \\
Our firm is using a transactional capability which goes beyond interactional \\
capability to offer transactional services such as an online purchasing capability \\
for customers to purchase products, track orders, and manage their account \\
information.
\end{tabular}

The least frequent phases that have been utilized by most of the Malay women entrepreneurs are Integrated E-Commerce students with the lowest mean score of 1.30. It shows that only a few of the entrepreneurs are using a transformational capability, where the firm's website is integrated with suppliers, customers, and other back-office systems allowing most business transactions and processes to be conducted electronically. To conclude, Malay women entrepreneurs still lack of awareness about the benefits of utilizing E-Commerce. Malay women entrepreneurs in Kuching Sarawak were only utilizing the early phases of E-Commerce in doing their business activities.

\section{Relationship between factors towards E-Commerce adoption by Malay women entrepreneurs (RO}

2).

This analysis was used to explain whether the pattern of the relationship between the independent variables towards the dependent variable. In this study $(n=93)$, the results displayed a positive correlation between perceived relative advantage with Pearson $r$-value of 4.71 and $p$ value $<0.005$ (0.000). The correlation between perceived compatibility and the E-Commerce adoption is negative, with Pearson r-value of -0.082 and $p$ value $<0.005(0.473)$. There is a negative correlation between perceived complexity with the E-Commerce adoption with Pearson $r$-value of -0.012 and $p$ value $<0.005$ (0.910). The correlation between cost with the E-Commerce adoption is also negative, with Pearson rvalue of -0.381 and $\mathrm{p}$ value $<0.005(0.000)$. There is negative correlation between organizational readiness with E-Commerce adoption with Pearson $r$-value of -0.021 and $p$ value $<0.005$ (0.843). Top management support has a positive correlation with the adoption of E-Commerce with Pearson r-value of 0.031 and $\mathrm{p}$ value $<0.005(0.767)$. The correlation between buyer/supplier pressure with the ECommerce adoption is positive, with Pearson $r$-value of 0.105 and $\mathrm{p}$ value $<0.005$ (0.318). For competitive pressure, it shows that the variable has a positive correlation in the adoption of ECommerce, where the Pearson r-value of 0.283 and $p$ value $<0.005$ (0.004). Supporting industries has a negative correlation with E-Commerce adoption, with Pearson $r$-value of -0.114 and $p$ value $<0.005$ (0.276). Government support has a positive correlation with E-Commerce adoption, where the Pearson $\mathrm{r}$-value is -0.381 and $\mathrm{p}$ value $<0.005(0.000)$. For the benefits of E-Commerce, it has a positive correlation with Pearson r-value of 0.084 and $\mathrm{p}$ value $<0.005$ (0.425). Lastly, for the barriers of ECommerce, it has a negative correlation with the E-Commerce adoption, with Pearson r-value of -0.026 and $\mathrm{p}$ value $<0.005(0.803)$. 
Table 4.3

Correlation Coefficient Values of Factors Influencing E-Commerce Adoption by Malay Women Entrepreneurs in Kuching Sarawak. $(N=93)$

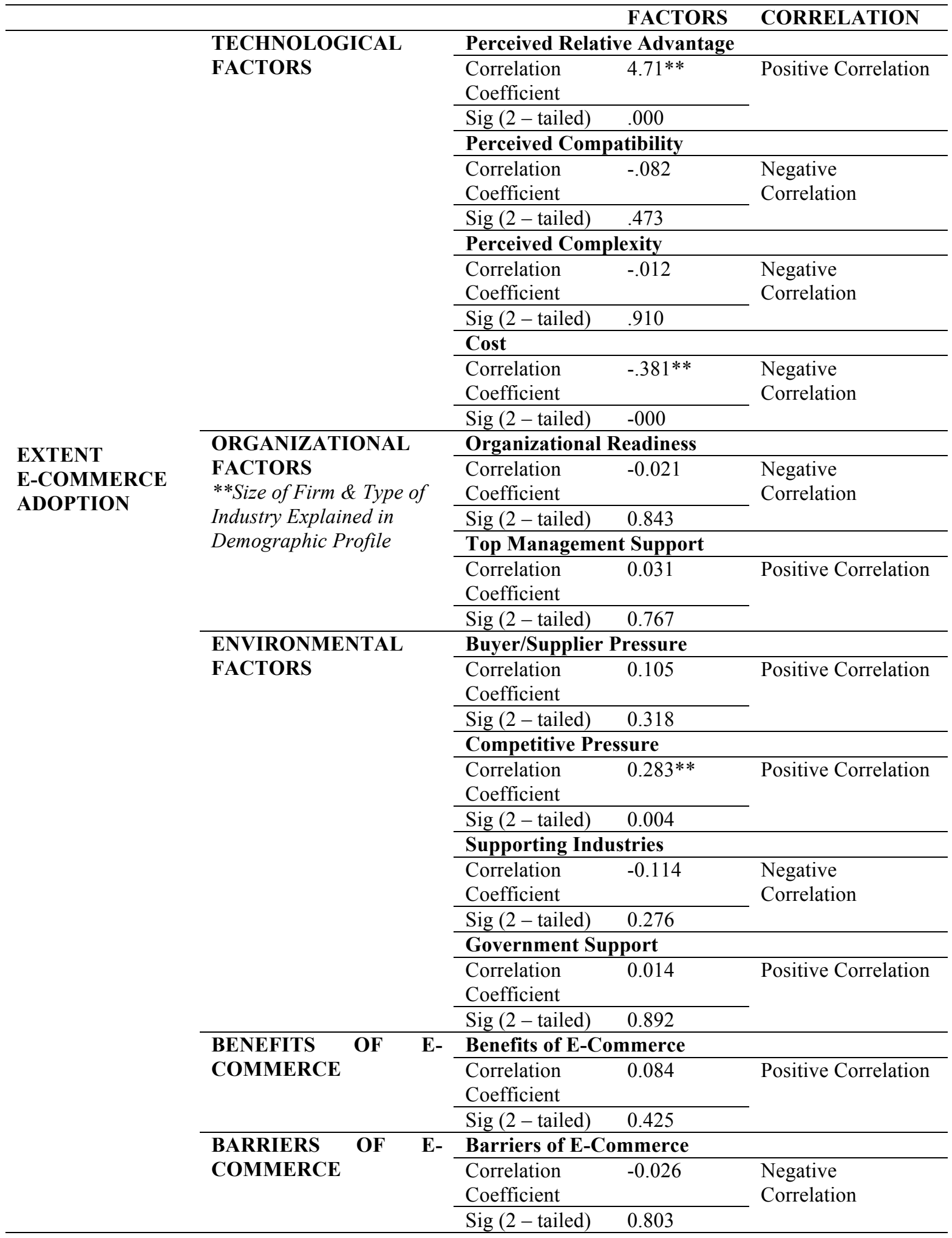


Strength of relationship between factors influencing E-Commerce adoption by Malay women entrepreneurs (RO 3).

Table 4.4

Result of Regression Analysis on Factors Influencing E-Commerce Adoption by Malay Women Entrepreneurs in Kuching Sarawak. (N=93)

\begin{tabular}{|c|c|c|c|c|c|c|}
\hline CONSTRUCT & & $\boldsymbol{\beta}$ & $\mathbf{R}^{2}$ & $\Delta \mathbf{R}^{2}$ & $\mathbf{t}$ & $\rho$ \\
\hline \multirow{4}{*}{$\begin{array}{l}\text { TECHNOLOGICAL } \\
\text { FACTORS }\end{array}$} & $\begin{array}{l}\text { Perceived } \\
\text { Advantage }\end{array}$ & 0.471 & 0.222 & 0.222 & 5.097 & 0.000 \\
\hline & Perceived Compatibility & -0.082 & 0.007 & 0.007 & -0.781 & 0.437 \\
\hline & Perceived Complexity & -0.012 & 0.000 & 0.000 & -0.113 & 0.910 \\
\hline & Cost & -0.381 & 0.146 & 0.146 & -3.937 & 0.000 \\
\hline \multirow{2}{*}{$\begin{array}{l}\text { ORGANIZATIONAL } \\
\text { FACTORS }\end{array}$} & Organizational Readiness & -0.021 & 0.000 & 0.000 & -0.198 & 0.843 \\
\hline & Top Management Support & 0.031 & 0.001 & 0.001 & 0.297 & 0.767 \\
\hline \multirow{4}{*}{$\begin{array}{l}\text { ENVIRONMENTAL } \\
\text { FACTORS }\end{array}$} & Buyer/Supplier Pressure & 0.105 & 0.011 & 0.011 & 1.005 & 0.318 \\
\hline & Competitive Pressure & 0.283 & 0.080 & 0.080 & 2.810 & 0.005 \\
\hline & Supporting Industries & -0.114 & 0.013 & 0.013 & -1.095 & 0.276 \\
\hline & Government Support & 0.014 & 0.000 & 0.000 & 0.136 & 0.892 \\
\hline $\begin{array}{l}\text { BENEFITS OF E- } \\
\text { COMMERCE }\end{array}$ & Benefits of E-Commerce & 0.084 & 0.007 & 0.007 & 0.802 & 0.425 \\
\hline $\begin{array}{l}\text { BARRIERS OF E- } \\
\text { COMMERCE }\end{array}$ & Barriers of E-Commerce & -0.026 & 0.001 & 0.001 & -0.251 & 0.803 \\
\hline
\end{tabular}

Result of the linear regression analysis shows that for this sample $(n=93)$, perceived relative advantage are significant predictors for the adoption of E-Commerce (beta $=0.741 ; \mathrm{p}$ value $\leq 0.005$ $(0.000)$ ) which these variables contributed $22.2 \%$ of the variation in the E-Commerce adoption $\left(\mathrm{R}^{2}=0.222\right)$. Linear regression result indicates that perceived compatibility is not a significant predictor in E-Commerce adoption (beta $=-0.082 ; \mathrm{p}$ value $>0.005(0.437)$ ) which the independent variables contributed $0.7 \%$ of the variation in the E-Commerce adoption $\left(\mathrm{R}^{2}=0.007\right)$. Linear regression analysis shows results of perceived complexity (beta $=0.012 ; \mathrm{p}$ value $>0.005(0.910)$ ), indicating that perceived complexity is not a significant predictor upon E-Commerce adoption among SMEs where these predictors contribute $0 \%$ of the variation in the E-Commerce adoption $\left(\mathrm{R}^{2}=0.000\right)$. The findings show that cost is a significant predictor with E-Commerce adoption intentions (beta $=-0.381$, $p$-value $\leq 0.005$ $(0.000)$ ) which contribute $14.6 \%$ of the variation in the E-Commerce adoption $\left(\mathrm{R}^{2}=0.146\right)$. Regression analysis organizational readiness showed it is not a significant predictor over the adoption of ECommerce (beta $=-0.021$, p-value $>0.005(0.843)$ ) where it contributed $0 \%$ of the variation in the ECommerce adoption $\left(\mathrm{R}^{2}=0.000\right)$. For top management support, it is also not a significant predictor in the adoption of E-Commerce (beta $=0.741 ; \mathrm{p}$ value $\leq 0.005(0.767)$ where it contributes $0.1 \%$ of the variation in the E-Commerce adoption $\left(\mathrm{R}^{2}=0.001\right)$. Linear regression analysis shows results of buyer/supplier pressure (beta $=0.105, \mathrm{p}$-value $>0.005(0.318)$ ), indicating that buyer/supplier pressure has negative effect in predicting E-Commerce adoption among Malay women entrepreneurs where it contributes $1.1 \%$ of the variation in the E-Commerce adoption $\left(\mathrm{R}^{2}=0.011\right)$. Linear regression analysis shows results of competitive pressure (beta $=0.283$, p-value $\leq 0.005(0.005)$ ), implying that this factor is a significant predictor in E-Commerce adoption intentions. Both of these predictor variables contributed $8 \%$ of the variation in the E-Commerce adoption $\left(\mathrm{R}^{2}=0.080\right)$. The results shows that supporting industries (beta $=-0.114$, $p$-value $>0.005(0.276)$ ), indicating that supporting industries has a negative effect on predicting E-Commerce adoption which has contributed $1.3 \%$ of the variation in the E-Commerce adoption $\left(\mathrm{R}^{2}=0.013\right)$. Government support also has a negative effect on predicting $\mathrm{E}$ - 
Commerce adoption (beta $=-0.114$, p-value $>0.005(0.276)$ ) has contributed $0 \%$ of the variation in the E-Commerce adoption $\left(\mathrm{R}^{2}=0.000\right)$.

\section{The benefits and barriers of E-commerce adoption perceived by Malay women entrepreneurs (RO 4)}

Table 4.4

Mean Score Result for Benefits of E-Commerce Adoption Perceived by Malay Women Entrepreneurs in Kuching Sarawak $(N=93)$

\begin{tabular}{lcc}
\hline \multicolumn{1}{c}{ ITEMS } & MEAN & RANKING \\
\hline Provided access to new markets & $\mathbf{4 . 2 7}$ & $\mathbf{1}$ \\
Better access to wider range of customers & 4.17 & 2 \\
Improve business processes flow & 4.10 & 3 \\
Reduced inventory costs & 4.00 & 4 \\
Increase the efficiency in dealing with suppliers & 3.95 & 5 \\
\hline
\end{tabular}

Table 4.4 shows the highest ranking for the benefit of E-Commerce is provided access to new markets with the highest mean score of 4.27. The second highest is better access to wider range of customers with the mean score of 4.17. Improve business processes flow holds the third ranking with the mean score of 4.10. In the fourth ranking is a reduced inventory cost with the mean score of 4.00. For the lowest mean score of 3.95, it falls for the benefit of increase the efficiency in dealing with suppliers.

Table 4.5

Results of Mean Score for Barriers of E-Commerce Adoption Perceived by Malay Women Entrepreneurs in Kuching Sarawak (N=93)

\begin{tabular}{lcc}
\multicolumn{1}{c}{ ITEMS } & MEAN & RANKING \\
\hline Lack of skilled workers to handle or maintain E-Commerce & $\mathbf{4 . 2 3}$ & $\mathbf{1}$ \\
system & & 2 \\
Telecommunication infrastructure is not sufficient & 4.09 & 3 \\
Lack of standards/regulations from government on E-Commerce & 3.98 & 4 \\
Cost of setting up E-Commerce is high & 3.95 & 5 \\
E-Commerce is not as effective as traditional marketing channel & 3.88 & \\
\hline
\end{tabular}

It can be found that among these barriers, lack of skilled workers to handle or maintain ECommerce system is the most barriers that perceived by Malay women entrepreneurs in adopting ECommerce with the mean score of 4.23. A second highest barrier is telecommunication infrastructure is not sufficient with 4.09. For lack of standards/regulations from government on E-Commerce, the mean scores are 3.98. Cost of setting up E-Commerce is high holds the mean score of 3.95 while the least barriers that perceived by Malay women entrepreneurs are E-Commerce is not as effective as traditional marketing channel with 3.88 .

\section{CONSLUSIONS AND RECOMMENDATIONS}

The purpose of this study is to investigate factors affecting intention to adopt E-Commerce in the SMEs among Malay women entrepreneurs in Kuching Sarawak. This study also contributes to and extends our understanding of the E-Commerce as a medium for commercial use in their businesses. The researcher would be able to identify the rationales for adopting or rejecting the adoption of E-Commerce by Malay women entrepreneurs. The research was done under theoretical framework that was developed based on the previous study. The multiple regression and Pearson correlation analysis shows that relative advantage, cost and competitive pressure are important variables of E-Commerce adoption. 
It is expected since past literature has consistently shown that perceived relative advantage has a significant and positive influence on the adoption of E-Commerce. This in complementing with several previous researches (Ramdani, Chevers, \& Williams, 2013; Mohammed, Almsafir \& Alnaser, 2013; Ghobakhloo, Arias-Ananda and Benitez-Amado, 2011; Alam, Ali \& Jani, 2011; Ifinedo, 2011; Sin, 2009; Alam, Khatibi, Ahmad \& Ismail, 2008; Hussin \& Noor, 2005 and Seyal and Abd. Rahman, 2003). Based on the factors that have been used in this study, only perceived relative advantage, cost and competitive pressure has the ability in predicting level of E-Commerce adoption. This study also shows that Malay women entrepreneurs perceived benefits from adopting E- Commerce where it can provide access to new markets. It also shows that Malay women entrepreneurs in Kuching Sarawak have yet to utilize E-Commerce technologies despite having acknowledged perceiving the benefits that can be obtained by adopting E-Commerce. As Malaysian government grows in importance and priority for business worldwide, an understanding of the factors that influence Malay women entrepreneurs in Kuching Sarawak adoption of the E-Commerce is very useful.

Although the perception of benefits that can be obtained from the adoption of E-Commerce is fully acknowledged, however, there are still many of the Malay women entrepreneurs who have yet to adopt this new platform of doing commerce. This problem occurs due to the lack of awareness about the benefits that can be obtained by adopting E-Commerce. Government agencies/bodies must play a role in promoting benefits of E-Commerce to the Malay women entrepreneurs to the non-adopters. Government agencies like SMECorp, UPUB, DUBS, MATRADE, SMIDEC and other government agencies should create better awareness on the benefits of E-Commerce to encourage higher rate of adoption among Malay women entrepreneurs. Conversely, this can be done by having seminars or training sessions to allow Malay women entrepreneurs to evaluate their new inventions. In order to receive greater responses towards E-Commerce adoption, it is recommended that authority should give certificates a token and financial support to attend the seminar. Apart from that, top management should provide support and adequate pre-training to their employees on how to use E-Commerce systems in business at all levels must be ensured so that the employees should get comfortable with its use. Top management support is very important in the decision in adopting E-Commerce. Besides that, it is also suggested that these three factors that have a significant relationship with E-Commerce adoption in this study (perceived relative advantage, cost and competitive pressure) should be investigated further. There are still certain areas that need more investigations on how these factors influencing Malay women entrepreneurs in Kuching Sarawak. By doing that, the entrepreneurs will be improved and giving this knowledge sharing to the rests of entrepreneurs from other races also and it can build their interest for those who non-adopters.

\section{REFERENCES}

Agarwal, S., \& Prasad, J. (1998). A Conceptual and Operational Definition of Personal Innovativeness in the Domain of Information Technology. Information Systems Research. 9(2), 204-215.

Alam, S. S. (2009, February). ICT Adoption in Small and Medium Enterprises:an Empirical Evidence of Service Sectors in Malaysia. International Journal of Business and Management.

Alam, S. S., Ali, M. Y., \& Mohd. Jani, M. F. (2011 ). AN EMPIRICAL STUDY OF FACTORS AFFECTING ELECTRONIC COMMERCE ADOPTION AMONG SMEs IN MALAYSIA. Journal of Business Economics and Management, Volume 12(2), 375-399.

Alam, S. S., Khatibi, A., Sayyed, A. M., \& Ismail, H. (2007). Factors Affecting E-commerce Adoption in the Electronic Manufacturing Companies in Malaysia. International Journal of Commerce and Management, 17 (1/2), 125-139.

Alamro, S., \& Tarawneh, S. A. (2011). Factors Affecting E-Commerce Adoption in Jordanian SMEs. European Journal of Scientific Research, Vol.64, pp. 497-506. 
Al-Qirim, N. (2007). "The adoption of eCommerce communications and applications technologies in small businesses in New Zealand". Electronic Commerce Research and Applications, Vol. 6 No. 4, 462-473.

Awa, H. O., M. Nwibere, B., \& J. Inyang, B. (2010). The Uptake of Electronic Commerce by SMEs : A Meta Theoretical Framework Expanding the Determining Constructs of TAM and TOE Frameworks. Journal of Global Business and Technology, Volume 6, 1-28.

Boateng, R., Molla, A., Heeks, R., \& Hinson, R. (2010). Advancing E-commerce Beyond Readiness in a Developing Economy: Experiences of Ghanaian Firms. Journal of Electronic Commerce in Organizations.

C.Laudon, K., Traver, C. G., Alam, S. S., Saihani, S. B., \& Mohammed Noordin, A. A. (2009). Principles of e-Commerce. PEARSON MALAYSIA SDN.BHD.

Chwelos, P., Benbasat, I., \& Dexter, A. S. (2001). "Research report: empirical test of an EDI adoption model”. Information Systems Research, Vol. 12 No. 3, 304-321.

Damanpour, F. (1992). Organizational Size and Innovation. Organization Studies. 13(3), 375-402.

Davis, S. (1979). The Diffusion of Process Innovations. Cambridge: Cambridge University Press.

Dewan, S., \& Kraemer, K. L. (2000). Information technology and productivity: Preliminary evidence from country-level data. Management Science 46(4), 548-562.

Dixon, T., Thompson, B., \& McAllister, P. (2002). The value of ICT for SMEs in the UK: a critical literature review, Report for Small Business Service research programme. The College of Estate Management.

EBRD. (1994). European Bank for Reconstruction and Development, Transition Report: First Edition. London: EBRD.

Fuad, N., \& Bohari, A. M. (2011, July ). Malay Women Entrepreneurs in the Small and Medium Sized ICT-Related Business: A Study on Need for Achievement. International Journal of Business and Social Science, Vol. 2 .

Garicano, L., \& Kaplan, S. N. (2001). Beyond the hype: Making B2B e-commerce profi table. Capital Ideas 2.

Ghobakhloo, M., Arias-Aranda, D., \& Benitez-Amado, J. (2011). Adoption of E-Commerce Applications in SMEs. Industrial Management \& Data Systems, Vol. 111 , pp. 1238-1269.

Gilaninia, S. Y., Danesh, M., Amiri, S. J., Mousavian, B., \& Eskandarpour. (2011). Effective Factors on Adoption of E-Commerce in SME Cooperative. Interdisciplinary Journal of Contemporary Research in Business, 3(6), 144-161.

Grandon, E. E., \& Pearson, J. M. (2004). "Electronic commerce adoption: an empirical study of small and medium US businesses". Information and Management, Vol. 42 No. 1, 197-216.

Grover, V., \& Goslar, M. D. (1993). "The initiation, adoption, and implementation of telecommunications technologies in US organizations". Journal of Management Information Systems, Vol. 10 No. 1, 141-163. 
Hussin, H., \& Noor, R. M. (2005). INNOVATING BUSINESS THROUGH E-COMMERCE: EXPLORING THE WILLINGNESS OF MALAYSIAN SMEs. The Second International Conference on Innovations in IT.

Iacovou, C. L., Benbasat, I., \& Dexter, A. S. (1995). "Electronic data interchange and small organizations: adoption and impact of technology". MIS Quarterly, Vol. 19 No. 4, 465-485.

Ifnedo, P. (2011). Internet/e-business technologies acceptance in Canada's SMEs. Exploratory investigation Internet Research Vol. 21 No. 3, 255-281.

Jawahitha, S. (2004). Consumer Protection E-Commerce: Analysing the Statutes in Malaysia. The Journal of American Academy of Business March, 55-63.

Jeyaraj, A., Rottman, J. W., \& Lacity, M. C. (2006). "A review of the predictors, linkages, and biases in IT innovation adoption research". Journal of Information Technology, Vol. 21, No. 1, 1-23.

Khairul, A. A., \& Ahmad, M. (2005). Adoption of web site and e-commerce technology among Malaysian public companies. Industrial Management \& Data Systems 105(9), 1172-1187.

Khatibi, A., Thyagarajan, V., \& Seetharaman, A. (2003). E-commerce in Malaysia: Perceived Benefit and Barriers. VIKALPA 28(3), 77-82.

Kiong, L. V. (2004). Analysis of the State of E-Commerce Adoption by the SMEs in Northern Malaysia and Factors that Might Hinder its Adoption: An Empirical Study. University of South Australia, International Graduate School of Management Division of Business and Enterprise.

Laudon, K. C., Traver, C. G., Alam, S. S., Saihani, S. B., \& Mohamed Noordin, A. A. (2012). Principles of e-Commerce. Malaysia: Prentice Hall.

Laudon, K., \& Traver, C. (2001). E-commerce: Business, technology, society. Boston: Addison Wesley.

Lee, J. (2004). "Discriminant analysis of technology adoption behaviour: a case of internet technologies in small businesses". Journal of Computer Information Systems, Vol. 44 No. 4, 57-66.

Levenburg, N., Magal, S. R., \& Kosalge, P. (2006). "An exploratory investigation oforganizational factors and e-business motivations among SMFOEs in the US". Electronic Markets, Vol. 16 No. $1,70-84$.

Licker, P., \& Motts, N. (2000). Extending the benefi ts of e-commerce in Africa: Exploratory phase. Proceedings of the First Annual conference of the Global IT Management Association, (pp. 115-118). Memphis, Tennessee, USA.

Lydia M. MacKenzie. (2006). Use Of The Internet as a Business Tool by Small and Medium-Sized Enterprises (SMEs). United States: ProQuest Information and Learning Company.

Mansfield, E. (1968). Industrial Research and Technological Innovation: An Econometric Analysis. New York: Norton.

Mohammed, J. A., Almsafir, M. K., \& Alnaser, A. S. (2013). The Factors That Affects E-Commerce Adoption in Small and Medium Enterprise: A Review. Australian Journal of Basic and Applied Sciences, 7(10), 406-412. 
Molla , A., \& Licker, P. S. (2005a). E-commerce adoption in developing countries: a model and instrument. Information \& Management (42), 877-899.

Molla, A., \& Licker, P. S. (2005b). Perceived E-Readiness factors in E-Commerce adoption: an empirical investigation in a developing country. International Journal of Electronic Commerce 10(1), 83-110.

Organisation for Economic Corporation and Development. (2000). "Enhancing the Competitiveness of SMEs in the Global Economy: Strategies and Policies,". Statistical Papers for the Bologna Conference.

Panie, R., Kamarudin, N. L., \& Ali, E. A. (2012). Women Entrepreneurs : The Hardships Unveil. Asean Entrepreneurship Conference (AEC 2012). Malaysia: Asean Entrepreneurship Journal.

Premkumar, G., \& Roberts, M. (1999). "Adoption of new information technologies in rural small businesses". Omega: The International Journal of Management Science, Vol. 27 No. 4, 467484.

Ramdani, B., Chevers, D., \& Williams, D. A. (2013). SMEs' adoption of enterprise applications. Journal of Small Business and Enterprise Development, Vol. 20, pp. 735-753.

Raymond, L. (2001). "Determinants of website implementation in small businesses". Internet Research, Vol. 11 No. 5, 411-422.

Scupola, A. (2009). "SMEs' e-commerce adoption: perspectives from Denmark and Australia”. Journal of Enterprise Information Management Vol. 22 No. 1/2.

Sekaran, U., \& Bougie, R. (2010). Research Methods for Business (Fifth Edition ed.). United Kingdom: John Wiley \& Sons Ltd.

Seyal, A. H., \& Rahman, M. N. (2003). A preliminary investigation of electronic commerce adoption in small and medium enterprises. Brunei Journal of Global Information Technology Management, 6(2), 6-26.

Shah, A. S., Ali, M. Y., \& Mohd Jani, M. F. (2011). An empirical study of factors affecting electronic commerce adoption among SMEs in Malaysia. Journal of Business Economics and Management, 12(2), 375-399.

Sin, T. K. (2009). An Empirical Study of Internet-Based ICT Adoption among SMEs In Southern Malaysia. Malaysia: UMI Dissertation Publishing.

Sin, T. K. (2009). An Empirical Study of Internet-Based ICT Adoption Among SMEs in Southern Malaysia. Multimedia University Malaysia, Faculty of Business and Law. Malaysia: UMI Dissertation Publishing.

Spanos, Y. E., Prastacos, G. P., \& Poulymenakou, A. (2002). The relationship between information and communication technologies adoption and management. Information \& Management (39), 659-675.

Teo, T. L. (2004). Factors affecting E-Commerce Adoption by SMEs: A Meta Analysis. Proceedings of the Australasian Conference on Information Systems. Tasmania: Australia. 
Thong, J. (1999). "An integrated model of information systems adoption in small businesses". Journal of Management Information Systems, Vol. 15 No. 4, 187-214.

Tornatzky, L. G., \& Klein, K. J. (1982). Innovation characteristics and innovation adoption implementation: a meta-analysis of findings. IEEE Transactions of Engineering Management, $29,28-45$.

Tornatzky, L., \& Fleischer, M. (1990). The Process of Technology Innovation. Lexington, M. A.: Lexington Books.

Troye, W. A. (1998). What is Electronic Commerce? Electronic Commerce, EU Policies and SME's. Retrieved November 6, 2016, from WWW.ispo.cec.be/E-commerce/poicies.htm.

UPUB. (n.d). Unit Pembangunan Usahawan Bumiputera Jabatan Ketua Menteri. Retrieved November 6, 2016, from Unit Pembangunan Usahawan Bumiputera: www.upub.sarawak.gov.my

Wang, J. C., \& Tsai, K. H. (2002). Factors in Taiwanese Firms' Decisions to Adopt Electronic Commerce: An Empirical Study. Cowley Road, Oxford: Blackwell Publishers Ltd.

Welter, F., Smallbone, Isakova, D. N., Aculai, E., \& Schakirova, N. (2004). “Women Entrepreneurs in the Ukraine, Republic of Moldova and Uzbekistan: Results of a Comparative Study" in UNECE, eds. Access to Financing and ICT: Women Entrepreneurs in the ECE Region. Geneva: United Nations.

Yap, C. S. (1990). "Distinguishing characteristics of organizations using computers". Information and Management, Vol. 18 No. 2, 97-107.

Yap, J., \& Tuah, Y. (2013, March 10). Women at the forefront. Borneo Post Online. Sarawak, Malaysia. Retrieved from Women at the forefront.

Zhu, K., Kraemer, K., \& Xu, S. (2003). Electronic Business Adoption by European Firms: A CrossCountry Assessment of the Facilitators and Inhibitors. European Journal of Information Systems, 12, 251-268. 